\title{
Professor Manuel José Barbanoj Rodriguez
}

On December 11, 2010, Manuel José Barbanoj Rodriguez, MD, full professor at the Department of Pharmacology and Therapeutics, Universitat Autònoma de Barcelona (UAB), Hospital de la Santa Creu i Sant Pau (HSCSP), shockingly passed away during a party celebrating his 50th birthday. Death came in the middle of joy, laughter and dancing when Manuel was celebrating to have overcome a myocardial infarction and the sequels of 4 bypasses, having been discharged from the hospital on July 9, 2010.

This is not only a great loss to his mother, friends and the academic staff of the Department of Clinical Pharmacology, Facultat de Medicina, UAB/HSCSP, but also to many colleagues and friends around the world, and specifically to the International Pharmaco EEG Group (IPEG), for which Prof. Barbanoj acted as President. Last but not least, his death will be felt with regret in the pharmaceutical industry, as he participated in 366 clinical trials.

During his short life, he gathered valuable experience in general clinical pharmacology, CNS pharmacology, sleep research, pharmaco-EEG and pharmacopsychology. He participated mostly in phase 1 , but also phase 2 and phase 3 trials, in 62 as collaborating investigator, in 147 as principal investigator and in 158 as scientific director. His expertise covered a broad field, reaching from psychopharmacological methodology to pharmacokinetics (PK), pharmacodynamics (PD) and PK/PD modelling.

Manuel José Barbanoj Rodriguez was born on December 10, 1960 in Terrassa (Barcelona), Spain. He obtained

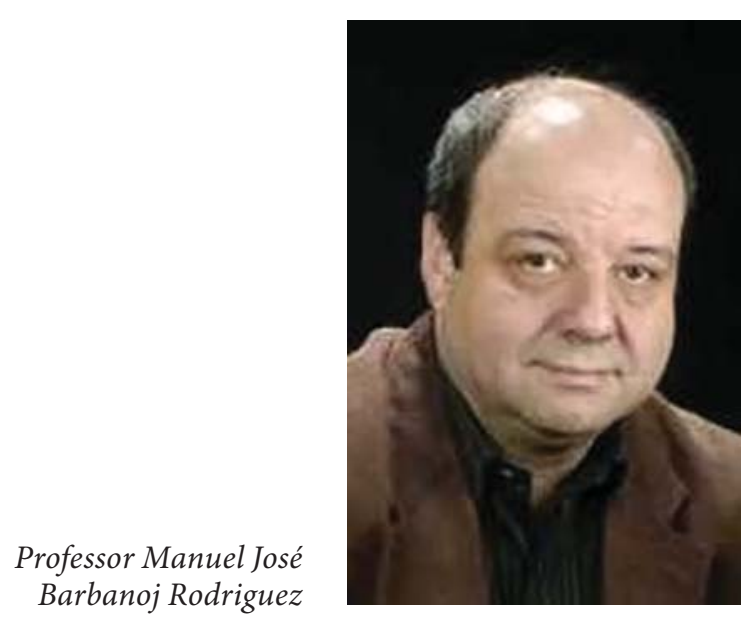

his MD in 1985, became a specialist in the field of clinical pharmacology in 2001 and got his second doctorate as $\mathrm{PhD}$ in the same year. On the latter occasion, where I had the privilege to participate, he defended his thesis against a 'tribunal' questioning him in 3 different languages (Catalonian, Castilian and English), with me representing the English examiner. This examination took place in the beautiful modernist chapel of the HSCSP, with the subsequent party overlooking Barcelona onto the Sagrada Familia and celebrating the arrival of the Spanish Academia in the European Union. In 1998, Manuel José Barbanoj Rodriguez also obtained a Master Degree in

\section{KARGER}

Fax +4161306 1234

E-Mail karger@karger.ch

www.karger.com
(C) 2012 S. Karger AG, Basel

0302-282X/12/0664-0199\$38.00/0

Accessible online at:

www.karger.com/nps 
Bioengineering at the Universitat Politècnica de Catalunya, received a Postgraduate Diploma in Experimental Pharmacology (Professional School of Pharmacologists), Universitat de Barcelona and Consejo Superior de Investigaciones Científicas, a Postgraduate Diploma in Medicine in the Pharmaceutical Industry, School of Medicine, $\mathrm{UAB}$, as well as a Postgraduate Diploma in Clinical Research Methodology, Escuela Nacional de Sanidad. In 2001, he became Medical Specialist in Clinical Pharmacology, Direcciòn General de Universidades and in 2003 he received a Postgraduate Diploma in Qualitative and Participative Research in Health Sciences, UAB.

His professional career proceeded from being a medical doctor at the Department of Clinical Pharmacology of the HSCSP in 1986 to becoming the Head of the Pharmacological Research Area of the Research Institute of the HSCSP (1993-1999). In 1995, he became a full professor at the Department of Pharmacology and Therapeutics, UAB and in 1999 the Head of the 'Centre d'Investigació de Medicaments de l'IR-HSCSP'. Between 1999 and 2000 he was also the Director of the Institut de Recerca of the HSCSP. Manuel José Barbanoj Rodriguez published over 141 articles in peer-reviewed journals and accumulated 290 impact points and 1,511 citations.

In 2000, Manuel José Barbanoj Rodriguez became editor of Somnus, Publicaciones Permanyer. In 2001, he joined the editorial staff of Human Pharmacology, Clinical and Experimental, Wiley, and between 2002 and 2005 was editor of Neuropsychobiology: Pharmacoelectroencephalography, the official journal of the International Pharmaco EEG Group (IPEG), Karger. In 2004, he was Director at the Vigila/Sueño, Doyma, the publication organ of the Associación Ibérica de Patología del Sueño (AIPS). He was reviewer for 19 journals, including Brain Research, Clinical Drug Investigation, Clinical Pharmacokinetics, Drug and Alcohol Review, Drug and Aging, Cognitive Brain Research, European Archives of Psychiatry and Clinical Neurosciences, Expert Review of Clinical Pharmacology, Human Psychopharmacology, Clinical and Experimental, Journal Expert Review of Neurotherapeutics, Journal of Clinical Psychopharmacology, Journal of Pharmaceutical and Biomedical Analysis, Medicina Clinica, Neuropsychobiology, Phytochemical Analysis, Psychopharmacology, Psychophysiology, Reumatología Clínica and Skin Pharmacology and Physiology.

Manuel José Barbanoj Rodriguez belonged to 10 scientific societies, including the Sociedad Española de Farmacología, Sociedad Española de Farmacología Clínica Hospitalaria, Societat Catalana de Farmacologia, International Pharmaco EEG Group, British Association for
Psychopharmacology, Sociedad Española de Psiquiatría Biológica, International Society for Neuroimaging in Psychiatry (ISNIP), Sociedad Española de Psicofisiología Cognitiva, Asociacíon Ibérica de Patología del Sueño and European Sleep Research Society (ESRS).

He was elected officer at the Junta Directiva de la Sociedad Española de Psicofisiología Cognitiva (1991-1995), Secretary of the Societat Catalana de Farmacologia (19921997), Vice President of the International Pharmaco EEG Group (IPEG) (2002-2008) and President of the IPEG (2008 until his death).

Between 1985 and 2008 he won 16 prizes in addition to 9 scholarships between 1996 and 1997.

He served at various times in 3 hospital commissions of the HSCSP and in 7 external commissions such as the Grupo de Expertos del Fondo de Investigaciones Sanitarias (FIS), Biomed2/European Commission, TV3, Agencia Nacional de Evaluación y Prospectiva (ANEP), Àrea de Trabajo sobre Farmacología de la Sociedad Española de Sueño (SES) and European Clinical Research Infrastructures Network.

He loved to come to Vienna and work with us at the Department of Psychiatry, University of Vienna, Section of Sleep Research and Pharmacopsychiatry for 3 months in 1988, for 1 month in 1989 and for 2 months in 1991. In 2001, he became a founding shareholder of our joint endeavour The Siesta Group Schlafanalyse GmbH, whose aim is to perform and analyse studies on human sleep and develop software tools and appliances to measure and analyse sleep-related data in order to create standards for studies on human sleep.

Manuel José Barbanoj Rodriguez was on the organization committees of many congresses, including the European Congress of Psychophysiology (1994), the 12th Congress of the Spanish Society of Clinical Pharmacology as Vice President (1996), the 8th CENP (Central European Neuropsychopharmacological) Symposium (1998) and the IPEG Training Course and Symposium as President of the Local Organizing Committee (2002).

Manuel José Barbanoj Rodriguez was indeed an active and cheerful man interested in life, culture, music and fine arts, but specifically also good food, also having been involved in the organization of a restaurant for a few years. He established contacts to many scientists all over the world and was equally liked by colleagues and patients. His decease is a big loss to all of us, but he will live in our hearts forever.

Bernd Saletu, MD

Professor of Psychiatry Medical University of Vienna, Austria 